\title{
Couples infected with hepatitis viruses and assisted reproductive technologies: management and outcome
}

\author{
Andreea Velişcu*, Bogdan Marinescu, Mihai Mitran, Marilena Băluță, Lucia Costoiu, Cristina Damian
}

From The 9th Edition of the Scientific Days of the National Institute for Infectious Diseases Prof Dr Matei Bals Bucharest, Romania. 23-25 October 2013

\section{Background}

How do infected couples (one or both partners) with hepatitis viruses and infertility achieve pregnancies? We need to assess the quality of embryos, sperm and pregnancies rates.

\section{Methods}

We performed a retrospective study in our clinic over a period of 5 years. We selected all couples infected with hepatitis viruses (one or both partners) that underwent an in vitro fertilization procedure or intrauterine insemination. We studied pregnancy rates, birth rates compared to a control group and quality of embryos and sperm (in infected males).

\section{Results}

The sperm parameters are lower in infected men when compared to the control group and there are fewer embryos for the infected couples, but pregnancies rates are comparable between the two groups.

\section{Conclusion}

All infected couples should have access to reproductive techniques with normal pregnancy rates.

Submit your next manuscript to BioMed Central and take full advantage of:

- Convenient online submission

- Thorough peer review

- No space constraints or color figure charges

- Immediate publication on acceptance

- Inclusion in PubMed, CAS, Scopus and Google Scholar

- Research which is freely available for redistribution
() Biomed Central

\footnotetext{
* Correspondence: andreea_veliscu@yahoo.com

Clinical Hospital of Obstetrics and Gynecology "Prof. Dr. Panait Sârbu",
}

Bucharest, Romania

(c) 2013 Velişcu et al; licensee BioMed Central Ltd. This is an Open Access article distributed under the terms of the Creative Commons 